\title{
Description new species from leafhopper belongs to genus Neoalitarus Distant, 1918 in Iraq
}

\author{
Rawa' J. H. Al-Kaissy and Hassan S. Al-Asady \\ Department of Bilgy, College of Education for Pure Science (Ibn Al-Haitham), University of Baghdad, Baghdad, \\ Iraq (corresponding author's phone:+9647700280624; e-mail: rawaaalkaissy@gmail.com) \\ (rawaaalkaissy@gmail.com)

\begin{abstract}
The present study introduces description of a new species genus Neoalitarus it is Neoalitarus nigrosus. This study includes external morphological characters and the spotting patterns and photos of vertex face pronotum, mesonotum, shape of male abdominal basal, male genitalia including; aedeagus, connective, genital style and genital plate and also female genitalia, seventh abdominal sternum, ovipositor including: middle valve and lower valve in addition venation systems on fore and hind wing.

The species under study regarded as a new record to Iraqi fauna of Cicadellidae. The specimens were collected from Al-Najaf province in May 2014.
\end{abstract}

Keywords: Neoalitarus nigrosus, Cicadellidae, Hemiptera

\section{Introduction}

The family of Cicadellidae is one of the largest families with order Hemiptera, includes more than 40 subfamily [1] and is a sub-family Deltocephalinae of the biggest sub-families it has 38 tribes and 923 genus and about 6683 species [2]; given the nature of feeding these people, they prefer planted juice for the bark, the wood of the vascular plant and the herbs are the main reason for many viruses are transported from plant to another causing the several of economic damage [3]. The genus Neoalitarus distant, 1918 the return to the Deltocephalinae's sub-family, which is characterized by the spindle body and the length of the male and female is between 3.2-4.5 mm and the head is rounded and the dark brown colour is predominant on the fore wing of its members [4].

\section{Materials and Methods}

The samples were collected using the sweeping net and the light trap, and the sample was obtained from the Iraqi Natural History Museum, as paste the sample on the $1 \times 1 \mathrm{~cm}$ white papers, then save inside the insect box, and record the information about the sample in terms of location and date collection, then recorded the morphological characteristic of the sample and the body parts was separated [5] and photographed the follow vertex, face, pronotum, and fore wing by Digital camera and with different zoom powers for the microscope. Both the mesonotum and the hind wing were then painted by the anatomy microscope, and the male genitalia was separated and placed in a test tube containing $10 \% \mathrm{KOH}$ for the ease of separating its parts, then put the male genitalia in alcohol $70 \%$ and then in the glycerin, and then examine the zoom powers for compound microscope [6]. 


\section{Results}

This species is Neoalitarus nigrosus sp. nov. New to the world the name has been derived from the dark black colour which is predominant on the body.

Body: Black with several yellow and white spots, male and female length 3.5-4 mm (picture 1).

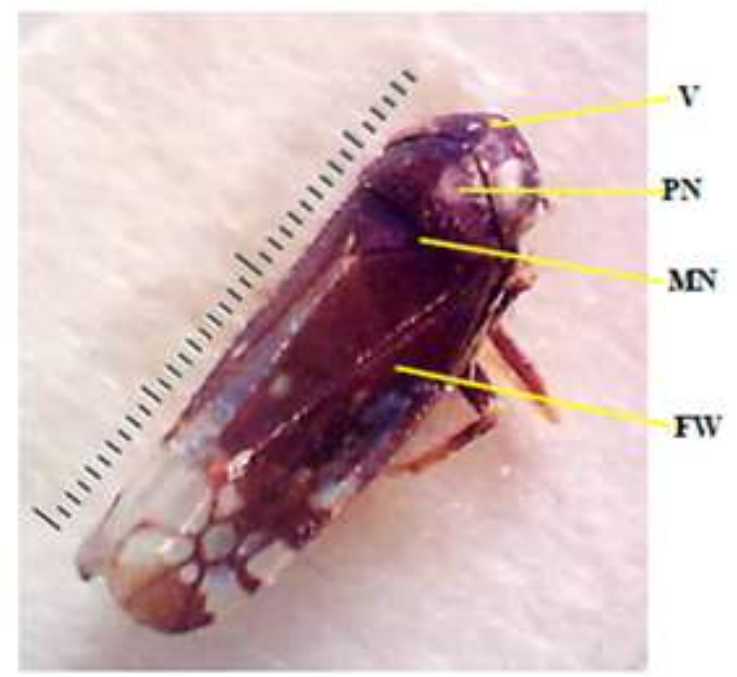

Pic. 1 Adult Insect $\hat{\jmath}(4 \mathrm{x})$

Vertex: Dark-arched black, its front margin round with a pair of irregular yellow spots and a star-shaped yellow spot when centered, compound eye CE brown dark, coronal suture CSu is unclear, posterior margin PM a little convex, posterior lateral angle PLA round with a pair of yellow spots cornea-shaped (picture 2).

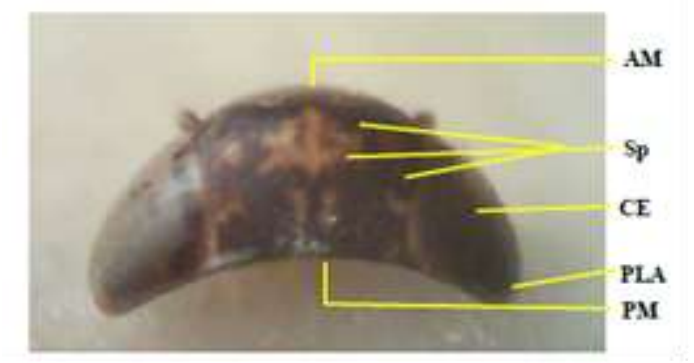

Pic. 2 Vertex (10x)

Face: Black, black frotoclypeus FC with several non-regular yellow stripe spots, the epistomal suture EPSSu is a little convex. The gena $\mathrm{G}$ length as well as lorum LO, the compound eye CE brown kidney-shaped, the anteclypeus AC is almost a round-ended widescreen (picture 3).

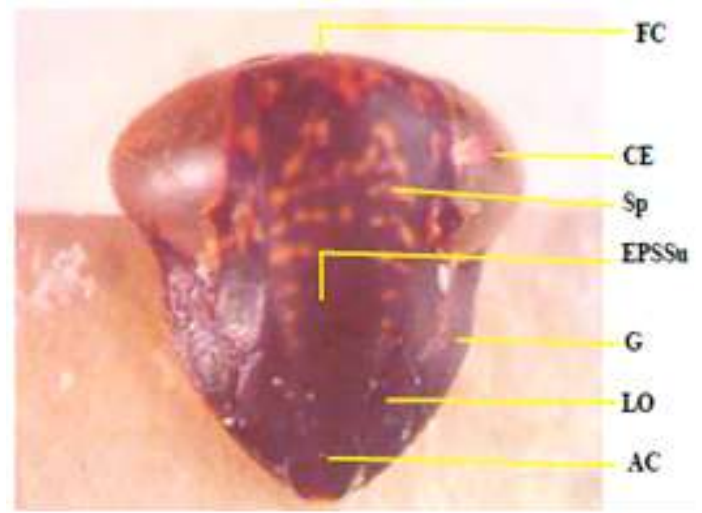

Pic. 3 Face (10x) 
Pronotum: Black with irregular yellow spots scattered on its surface, anterior margin AM round, posterior lateral angle PLA cut and obligate, posterior margin PM is slightly arc (picture 4).

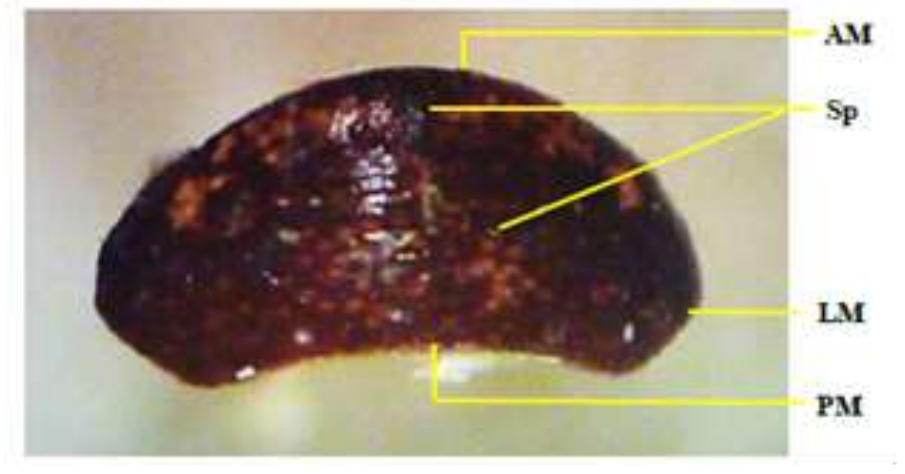

Pic. 4 Pronotum (10x).

Mesonotum: Prescutum PS dark-margind (black), its top slightly tapering, scutum ST. dark- brown with distinctive spot, scutellar suture SLSu is clear and rounded, lateral angle LA cut obligate, scutellum SL darkbrown funnel-shaped emerged from it a small prominence (Figure 1).

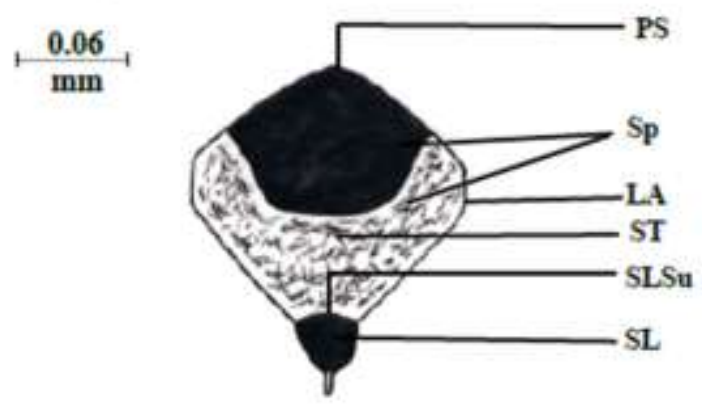

Fig. (1): Mesonotum (10x)

Fore wing: black with white spots centered on the apical third, the costal margin curved, the posterior margin straight and with a fade at the apical third, its apical round and obligate, there's a cross-sectional in the clavus region CL, the anal vein is curved inward, internal apical cell IAC polygonal, median apical cell pyramidal longitude and the largest of the cells, external apical cell EAC is a triangle form, subcostal apical cell is longitude, corio-claval suture CCSu reach to internal apical cell, median vein M not up to the top of the wing, radius vein $\mathrm{R}$ up to the top wing (picture 5).

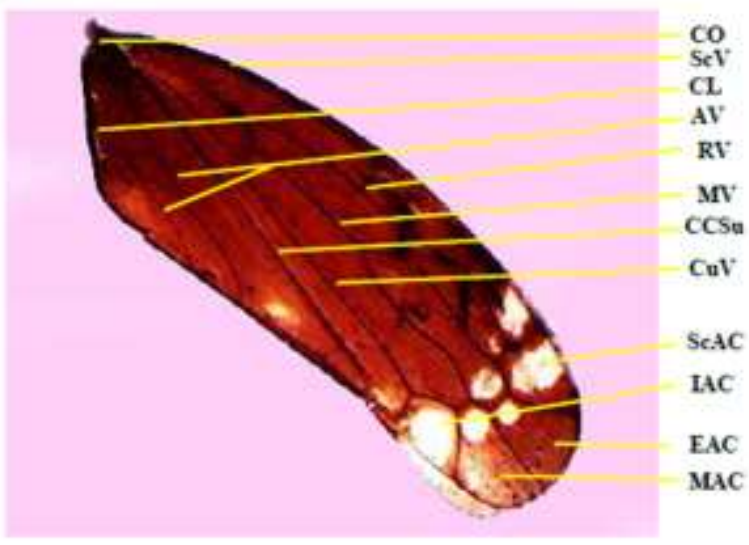

Pic. 5: Fore wing (10x). 
Hind wing: Transparent with a characteristic irregular brown spot at the costal angle, cut and obligate top, subcostal Sc and radius R veins branches, Subcosta2 (Sc2) and Rs are union at cross-vein and connect to two dots with peripheral vein P.V., the anal vein A1, linear and straight, anal vein A2 is straight and short and they both unite as triangle with the peripheral vein, the anal vein A3 straight, there are two dizziness anal AF1, AF2, which represent the boundaries of the wing folds (Figure 2).

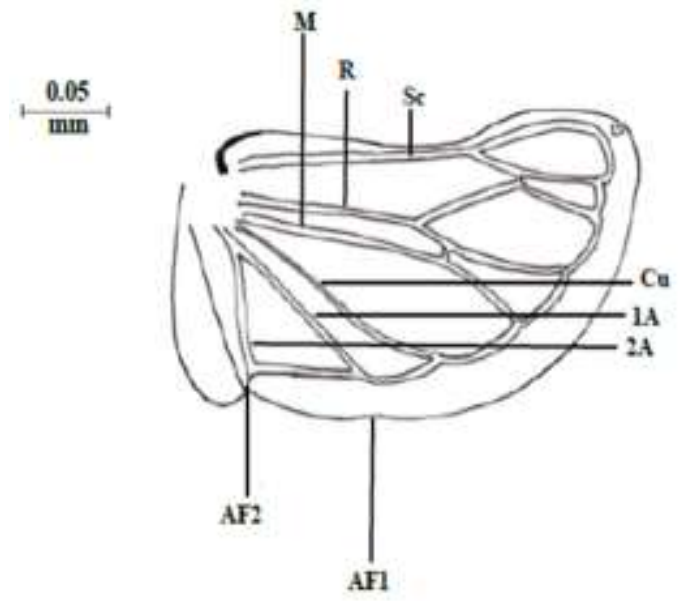

Fig. 2: Hind wing

Male genitalia

Aedeagus: A short their top round with a pair of similar lateral prominence dangling to the both sides with a distinctive fade note at the bottom of the top and a small base which develops it into two identical halves (Figure A3).

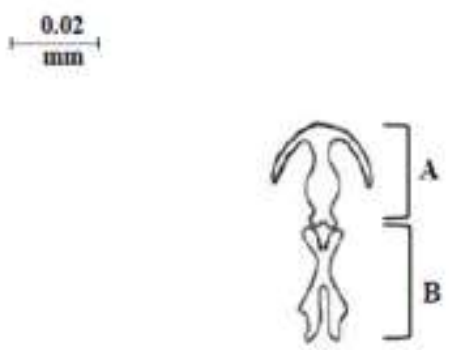

Fig. 3: A- Aedeagus B- Connective

Connective: Its top scattered to the identical similar halves, with a narrow base similar to scissors, corset clearly in the middle of it (Figure B3).

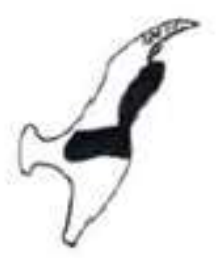

Fig. 4: Genital style 
Genital style: longitude, a prominence top-like claw with a high single spine beneath the lower lateral margin, its base taper and narrow, inner margins are smooth winding, outer margin with a hammer-like prominent at one third of the base (Figure 4).

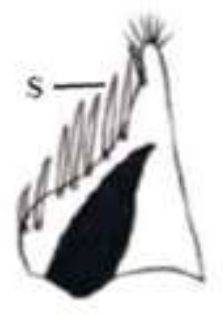

Fig. 5: Genital plate

Genital plate: It's a small, prominence, round-shaped, marked by eight bristles with arc-shaped, its base roughly plane, outer margin with a row of speckles almost identical in size occupies most of the margin, the posterior lateral angle has a number of small bristles, its interior margin is straight, smooth and sleek (Figure 5).

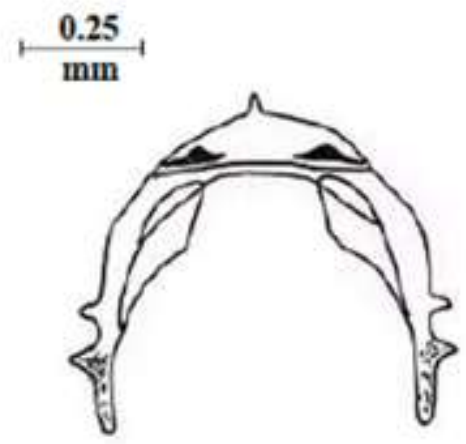

Fig. 6: Male Basal Abdominal Apodeme

Male basal abdominal as in Figure 6.

Female genitalia

Seventh Abdominal Sternum: The general color of the dark brown, anterior margin AM taper and prominent a little salient forward, posterior margin PM a little convex with a white strep at the center and at the angle of the posterior lateral angle PLA, the lateral margin LM is oblique (Figure 7).

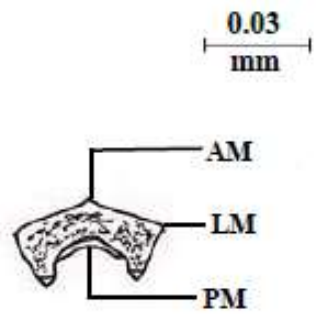

Fig. 7 Female 7th Abdominal Sternum 


\section{Ovipositor (Figure 8)}

Middle valve V2: Its outer margin, with a regular small indentation near the sharp peak, its inner margin with sharp indentations.

Lower valve V1: Its outer margin is smooth, its inner margin with irregular indentations with tapered apex, high surface with very small speckles.

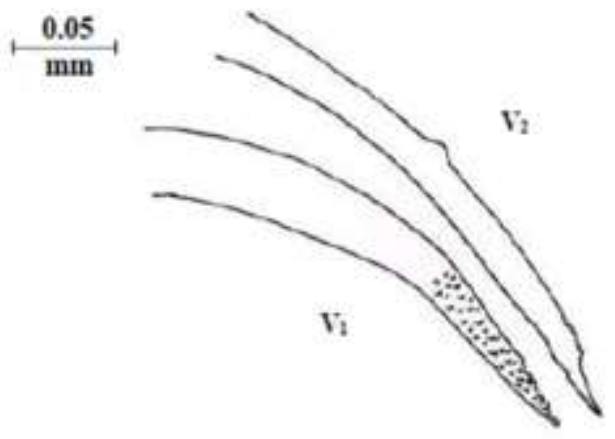

Fig. 8 Ovipositor

Examined Samples: One male §̊ holotype

Two males $\delta$ Paratype + eight female + paratype

Places of collection: Holy Al-Najaf Governorate, May 2014

This type is Neoalitarus nigrosus sp. nov. Similar to the type Neoalitarus fenestratus Herrich-Schäeffer, 1964, the similar type differs from the following:

- Vertex is firmly arched, dark and its anterior margin is a little round and prominent forward with a yellow irregular spots, posterior margin is heavily convex, the posterior lateral angle is round.

- Mesonotum: Prescutum light brown and their top a little round and prominent forward, prescutum light brown without spots, scutellar suture is not full, the lateral angle is a prominent and tapered, scutellum is a triangle and a free sharp end.

- Aedeagus is shorter same as the anchor, there is a clear hiding at the bottom of the base, a broad base.

- Genital style is a narrow, non-spines, narrow and skewed base toward out.

- Genital plate is a triangle, with a narrow and a spinal top, with its outer margin has a row of similar sizes spins, free of speckles [7].HELPFUL HINTS

\section{References}

[1] Wilson, M. R. \& Takiya, D. M. (2007). Cicadellinae (Hemiptera, Auchenorrhyncha: Cicadellidae) described by Leopold Melichar in the Hungarian Natural History Museum. Annales Historico-Naturales Musei Nationalis Hungarici 99: 29-48.

[2] Zahniser, J. N. \& Dietrich, C. H. (2013). A review of the tribes of Deltocephalinae (Hemiptera: Auchenorrhyncha: Cicadellidae). Europ. J. Taxon., 45: 1-211.

[3] Zahniser, J. N. \& Dietrich, C. H. (2008). Phylogeny of the leafhopper subfamily Deltocephalinae (Insecta: Auchenorrhyncha: Cicadellidae) and related subfamilies based on morphology. Systematics and Biodiversity 6(1): 1-24.

[4] Al-Asady, H. S. and Al-Gailany, H. B. D. (2003). External morphological study of the leafhopper Neoalitarus fenestratus Herrich-Schaeffer, 1964 (Homoptera: Cicadellidae) from Iraq. Bull. Iraq nat. Hist. Mus., 10 (1): 1-5.

[5] Huli \& Zhongl, Z. I. (2012). Anew genus and species of Agalliini from china (Hemiptera, Cicadellidae), Megophthal (Minae). Institute of Entomology, Guizhou. University, the provincial key laboratory for Agriculthuars pest management of mountainous region, Guiyana. Zootax. 3582: 1. 
[6] Cotanach, A. (2002-2009). A survey of leafhopper (Homoptera: Cicadellidae) on dominica, WI. Ann. Entomol. Soc. Am., 00(0)000-000(0000): 7.

[7] Tishechkin. D. Yu. (2007). Review of Neoaliturus fenestratus (Herrich-schäffer, 1834) (Homoptera: Cicadelidae) of the fauna of Russia. Russian. Entomol. J., 16(4): 415-424.

Rawa' J. H. Al-Kaissy (PhD. Lecture, University of Baghdad, Entomology).

Qualification: B. Sc. Biology 1995, M. Sc. Biology 2000, PhD. Biology 2016, Scientific Rank: Assistant Lecturer 2001, Instructor 2010, Address: University of Baghdad/ College of Education for pure Science (Ibn Al-Haitham)/ Department of Biology, Courses taught: Entomology and 8 publishing paper. 